УДК 616:89:053

DOI 10.11603/2411-1597.2021.3.12648

\title{
ПРАКТИЧНІ АСПЕКТИ ДІЯЛЬНОСТІ МЕДИЧНОЇ СЕСТРИ У НАЛАГОДЖЕННІ МІЖОСОБИСТІСНИХ ВЗАЄМИН В УЧНІВСЬКИХ КОЛЕКТИВАХ
}

\author{
М. С. Рибчинська, О. І. Пилипишин \\ Тернопільський національний медичний університет \\ імені І. Я. Горбачевського МОЗ Украӥни
}

У статті описано професійну діяльність медичної сестри 3 колективом учнів загальноосвітнього навчального закладу. Визначено роль медичної сестри у підвищенні рівня психологічного здоров’я підлітків в учнівських колективах.

\section{PRACTICAL ASPECTS OF NURSES' ACTIVITIES IN ESTABLISHING INTERPERSONAL RELATIONSHIPS IN STUDENT TEAMS}

\author{
M. S. Rybchynska, O. I. Pylypyshyn
}

\section{Horbachevsky Ternopil National Medical University}

The article describes the professional activity of a nurse with a team of students of a secondary school. The role of the nurse in improving the psychological health of adolescents while working in student groups has been identified.

Вступ. Питання створення, згуртування та удосконалення колективу, зокрема підліткового, були і $\epsilon$ актуальними на сьогодні. Кожен учень підліткового віку входить до складу багатьох колективів, які формуються та існують у найрізноманітніших сферах життєдіяльності, починаючи з навчальної (клас, школа, гурток). Тому психологічне здоров'я підростаючого покоління залежить від різних впливів у багатьох колективах.

Основна частина. Медична сестра може проводити з учнівським колективом підлітків заняття, спрямовані на покращення міжособистісних взаємин, що передбачає:

1) всебічне дослідження особливостей функціонування колективу підлітків;

2) спільне визначення значущих цілей та цінностей;

3) організацію різноманітної колективної діяльності групи;

4) вироблення традицій;

5) створення ситуацій успіху та тріумфу особистості;

6) індивідуальний підхід до розвитку особистості.

(c) М. С. Рибчинська, О. І. Пилипишин, 2021
Для вивчення учнівського колективу застосовують перевірені методи: спостереження; експеримент; опитування (анкетування, тестування, інтерв'ю, бесіди); аналіз продуктів діяльності; діагностичні методики [1]. Використовують:

- соціометричний тест Я. Морено призначений для діагностування емоційних зв'язків, тобто взаємних симпатій, між членами групи, а також для виявлення відносного авторитету членів групи за ознаками симпатії - антипатії;

- визначення індексу групової згуртованості;

- експрес-методику визначення соціальнопсихологічного клімату в колективі, яка допомагає виявити емоційний, поведінковий і когнітивний компоненти стосунків у колективі;

- тест сприймання індивідом групи - індивідуалістичний, прагматичний, колективістський. Визначальний показник типу сприймання - роль групи в особистісній діяльності підлітка;

- методику «Фотографія». Учні виступають в ролі фотографів та роблять «знімок» (групову фотографію) свого класу, розміщуючи на аркуші себе, однокласників, класного керівника. Варто звернути увагу на загальний настрій (фон) роботи, місце розташу- 
вання автора фотографії та інших учасників групового малюнку;

- методику «Незакінчені фрази», яка вимагає від дітей письмового продовження різноманітних тверджень типу: найближча мені людина в класі - це...; мені приємно проводити вільний час з...; я не спілкуюся з...; у разі необхідності я спілкуюся з...

Формування медичною сестрою високого рівня групової згуртованості забезпечують:

- особиста значущість для підлітків обговорення з фахівцем медицини медико-психологічних проблем;

- урахування інтересів учнів у розгляді особистісних психологічних проблем;

- створення сприятливої атмосфери у спілкуванні;

- правильна організація діяльності як джерела набуття особистого досвіду моральної поведінки та засобу формування ціннісних моральних мотивів для згуртування колективу.

Одним із засобів підвищення рівня групової згуртованості ми вказали створення ситуації успіху - методика підвищення самооцінки та розвитку впевненості підлітка у собі. Методика тріумфу особистості спрямована на усвідомлення ним свого місця в колективі. Для зазначених методик характерне спільне змістове наповнення: визнання досягнутих учнем очікуваних результатів будь-якого типу діяльності, але методики їх організації відрізняються між собою (табл. 1).

\section{Таблиця 1. Методика організації ситуації успіху та тріумфу особистості}

\begin{tabular}{|l|l|}
\hline \multicolumn{1}{|c|}{ Ситуація успіху } & \multicolumn{1}{|c|}{ Тріумф особистості } \\
\hline $\begin{array}{l}\text { Знімається страх перед } \\
\text { неуспіхом }\end{array}$ & $\begin{array}{l}\text { Висловлюється віра в } \\
\text { людину }\end{array}$ \\
\hline Високо мотивуються дії & $\begin{array}{l}\text { Визнається результат } \\
\text { діяльності }\end{array}$ \\
\hline $\begin{array}{l}\text { Подається схована } \\
\text { інструкція }\end{array}$ & $\begin{array}{l}\text { Зазначаються переваги } \\
\text { виконання }\end{array}$ \\
\hline $\begin{array}{l}\text { Відзначаються особисті } \\
\text { особливості }\end{array}$ & $\begin{array}{l}\text { Підкреслюється значення } \\
\text { результату }\end{array}$ \\
\hline $\begin{array}{l}\text { Відбувається педагогічне } \\
\text { навіювання }\end{array}$ & $\begin{array}{l}\text { Група (учень) отримує } \\
\text { високу оцінку у вигляді } \\
\text { визнання та вдячності }\end{array}$ \\
\hline $\begin{array}{l}\text { Позитивно оцінюються } \\
\text { деталі }\end{array}$ & \\
\hline
\end{tabular}

Для створення ситуації успіху та тріумфу особистості необхідні сприятливі умови успішності групи та кожного учня [2]:

- доброзичливість - відношення, коли всі вчинки підлітка оцінюються з точки зору його переваг («Він не хотів так вчинити...»);
- віра в сили та успіх кожного - відношення, основане на позитивній оцінці підлітка, переконаності в його перевагах, які обов'язково проявляються («У нього вийде...», «Вона незабаром зрозуміє, що...»);

- пошук істини - відношення до обставин або подій, коли увага спрямовується на причини того, що сталося, але не на оцінку поведінки учня, який став винуватцем негативних подій («Головне - зрозуміти, чому ти так вчинив...»);

- зосередженість - уміння направляти на щось свої думки, увагу, усі сили («На деякий час забудемо про все, крім нашої проблеми, бо вона вимагає розв'язання...»);

- адекватне сприйняття висловленого заперечення («Ми готові тебе вислухати...»).

Очікуючи від підлітків прояву активної життєвої позиції, необхідно вселяти впевненість та віру у власні можливості, дії кожного учасника. Ситуація успіху ґрунтується на особистому досягненні підлітка, і педагог помічає їі відразу, щоб група могла оцінити тріумф особистості.

Згуртуванню підлітків сприяє формування позитивного емоційного клімату в колективі у результаті спільних переживань щодо особистісно значущих життєвих явищ, подій учасників та спілкування у позашкільний час. Важливо вчасно зауважувати позитивні чи негативні зміни настрою учнів у класі. Формування колективного мислення визначається ще одним ефективним засобом покращення групової взаємодії. Підліток беручи активну участь у постановці чи вирішенні спільних завдань відчуває себе значущою частиною колективу, проявляє особисту ініціативність та критичність до недостатньо обґрунтованих пропозицій, що, у свою чергу, сприяє розвитку самокритичності. Колективне мислення формує сприятливий емоційний тонус групи.

Одним із важливих напрямів роботи медичної сестри в школі $\epsilon$ вивчення соціально-психологічних особливостей особистості [3] для згуртування дитячого колективу:

1. Групові тренінгові заняття - вчити підлітків самостійно аналізувати свою поведінку, визначати та усувати причини своїх комунікативних перцептивних труднощів, глибше пізнавати власну особистість, набувати досвіду людських взаємин, створювати позитивний мікроклімат у підлітковому колективі. 
2. Міні-лекція - це повноцінне та якісне інформування підлітків; переконання у необхідності та корисності отриманої інформації. Тривалість інформаційного повідомлення не має перевищувати 20-30 хв.

3. Мозковий штурм, або брейнстормінг, - можна використовувати для практичного розв'язання проблем, пов'язаних із взаєминами у колективі. Для цього визначається ключове слово, наприклад «взаємини», і окреслюються проблеми, які виникають у цьому зв'язку. У ході презентації визначених ідей і їхнього спільного обговорення обираються оптимальні розв'язки.

4. Рольова гра - засіб збагачення особистого досвіду підлітків шляхом створення несподіваної проблемної ситуації, що вимагає від них прийняття певних ролей з метою знаходження логічного вирішення завдання. Коли демонструється модель конфлікту між підлітками, то вони мають можливість побачити «підводні камені» проблеми та запропонувати шляхи виходу з неї. За словами Н. Мусатенко, гра допомагає виявити тенденції поведінки членів колективу: прагнення досягати успіху за рахунок поразки інших або здатність йти на поступки для того, щоб перемогти обом командам. Спостерігаючи за ходом гри та діями окремих учасників, медична

\section{СПИСОК ЛІТЕРАТУРИ}

1. Дудка В. В. Учимось долати бар'єри у спілкуванні / В. В. Дудка // Практичний психолог. - 2014. - № 7. C. 18-24.

2. Гречаник О. $Є$. Діяльність класного керівника з розвитку учнівського колективу / О. Є. Гречаник // Управління школою : науково-методичний журнал. - 2011. № 22-24. - С. 26-31. сестра може визначити індивідуальні особливості поведінки та взаємодії підлітків: навіюваність, конформізм, консерватизм або негативізм, гуманність. Гра може бути як діагностичним, так і корекційним методом. Ця методика дозволяє зробити висновки про деякі якісні характеристики психологічного клімату в колективі підлітків: доброзичливість чи суперництво, взаємна підтримка чи індивідуальний та груповий егоїзм [4].

5. Кейс-метод - дає можливість підліткам ідентифікувати свою поведінку під час вирішення групового конфлікту, шукати оптимальні шляхи вирішення проблем, які описані в ситуаціях.

6. Групова дискусія - може бути використана з метою надання можливості підліткам побачити проблему з різних сторін, що уточнює взаємні позиції, а також у якості групової рефлексії через аналіз індивідуальних переживань, що полегшує саморозкриття учасників.

Висновки. Соціально-психологічний клімат у підлітковому колективі визначається реальними взаєминами між підлітками, їх вміннями та навичками етичної взаємодії. Стабільність і згуртованість групи залежить від того, наскільки підліток має змогу самоствердитися, самовизначитися, знайти в ній емоційний захист.

3. Пенішкевич Д. І. Соціальна педагогіка: модульна технологія навчального курсу / Д. І. Пенішкевич, Л. І. Тимчук. - Чернівці : Чернівецький національний університет, 2010. - 496 c.

4. Мусатенко Н. В. Психологічний клімат колективу / Н. В. Мусатенко // Психолог. - 2008. - № 19. - С. 16-19. 